\title{
Enflasyon ve Dolaylı Vergiler Arasındaki Bağlantı: Türkiye Örneği
}

\author{
Umut AKDUĞ $\mathrm{AN}^{1}$
}

\section{$\ddot{O}_{z}$}

Dolaylı vergiler ile enflasyon arasındaki ilişkiyi inceleyen teorik ve ampirik çalışmalar, bu değişkenlerin karşılıklı olarak birbirini etkileyebileceğine ilişkin kanıtlar sunmaktadır. Genel olarak, bu çift yönlü ilişsinin enflasyondan dolaylı vergilere doğru olan kısmını, enflasyonist bir sürecin vergi matrahı üzerindeki etkisi açıklamaktadır. Diğer taraftan, dolaylı vergilerin enflasyon üzerindeki etkisi ise, vergi oranlarındaki değişmelerin fiyatları değiştirmesinden kaynaklanmaktadır. Çalışmanın amacı, Türkiye'de enflasyon ve dolaylı vergiler arasındaki nedensellik ilişkisinin araștıılması ve enflasyonun azaltılmasında bir maliye politikası aracı olarak dolaylı vergilerin etkin olup olmadığının belirlenmesidir. Bu doğrultuda; Türkiye'de 2004-2019 dönemi aylık verileri kullanılarak, enflasyon oranları ile dolaylı vergi gelirleri arasındaki nedensellik ilişkisi, VAR modellerine dayalı olarak gerçekleştirilen Granger ve TodaYamamoto (1995) nedensellik testleriyle araştırlmıştır. Elde edilen bulgular; dolaylı vergi gelirleri ile üretici fiyat endeksi (ÜFE) arasında herhangi bir nedensellik ilişkisinin olmadığını, tüketici fiyat endeksi (TÜFE)'den dolaylı vergi gelirlerine doğru tek yönlü bir nedensellik ilişkisi olduğunu göstermektedir. Ayrıca ARDL-Sınır testi sonucu, TÜFE ile dolaylı vergi gelirleri arasında uzun dönemli bir ilişki olduğunu ve bu ilişkinin negatif olduğunu göstermektedir. Diğer bir ifadeyle; incelenen dönemde enflasyon oranındaki bir artışın dolaylı vergi gelirlerinin reel değerini azalttı̆̆ı görülmüştür.

Anabtar Kelimeler: Dolaylı vergiler, Enflasyon, Granger Nedenselliği, Toda-Yamamoto yaklaşımı, Sınır testi

\section{The Relationship between Inflation and Indirect Taxes: The Case of Turkey}

\section{Abstract}

The theoretical and empirical studies which examine the relationship between indirect taxes and inflation provide evidences for which these variables may affect each other mutually. Generally, the part of this bilateral relationship from inflation to indirect taxes explains the impact of an inflationist process on the tax assessment. On the other hand, the effect of indirect taxes on inflation arises from the fact that changes in tax rates change prices. The aim of this study is to examine the causal relationship between inflation and indirect taxes in Turkey and is to determine, as a fiscal policy instrument in reducing inflation, whether indirect taxes are effective. In this direction; 2004-2019 monthly data for Turkey are used and causality relationship between inflation rates and indirect tax revenues is examined with Granger and Toda-Yamamoto (1995) causality tests which are generated on the basis of VAR models. The findings obtained show that there is no causality relationship between indirect tax revenues and producer price index (PPI), and there is a one-direction causality relationship from consumer price index (CPI) to indirect tax revenues. In addition, the result of the ARDL-Bound test shows that there is a long-term relationship between CPI and indirect tax revenues and this relationship is negative. In other words, it has been observed that the increase in the inflation rate in the analyzed period decreased the real value of indirect tax revenues.

Key Words: Indirect taxes, Inflation, Granger causality, Toda-Yamamoto Approach, Bounds test

\section{Atıf İçin / Please Cite As:}

Akduğan, U. (2020). Enflasyon ve dolaylı vergiler arasındaki bağlantı: Türkiye örneği. Manas Sosyal Araștrmalar Dergisi, 9(4), 2248-2262.

Geliş Tarihi / Received Date: 13.04.2020

Kabul Tarihi / Accepted Date: 08.06.2020

\footnotetext{
${ }^{1}$ Dr. Öğr. Üyesi - Trakya Üniversitesi İktisadi ve İdari Bilimler Fakültesi, umutakdugan@trakya.edu.tr ORCID: 0000-0001-8659-541X
} 


\section{Giriş}

Enflasyon ile dolaylı vergiler arasındaki ilişkiyi inceleyen önceki çalısmalara bakıldığında, bu iki değişken arasındaki ilişkinin çift yönlü olabileceği belirtilmektedir. Bu bağlamda; dolaylı vergilerin enflasyon oranı üzerinde bir etkisinin olması, maliyet enflasyonunu ve vergi kaynaklı enflasyonu ön plana çıkaracaktır. Gelir vergisi gibi dolaysız vergiler toplam talep yoluyla enflasyonu etkileyebilirken, mallar üzerinde koyulan dolaylı vergiler nihai fiyata yansımakta ve fiyat-ücret sarmalı vasıtasıyla maliyet enflasyonuna neden olabilmektedir. Diğer taraftan, enflasyonun dolaylı vergi gelirlerini etkilemesi durumunda ise, vergi gelirlerinin reel değerindeki değişimler ve enflasyon vergisi kavramı ya da toplam talepteki değişimler tartışlacaktır. Kamu harcamalarının büyük oranda vergi gelirleri ile finanse edilmesi durumunda enflasyondaki dalgalanmalar nedeniyle kamu gelirlerinde meydana gelecek reel azalma, kamu maliyesinde ve ekonominin genelinde ciddi olumsuzlukları beraberinde getirecektir.

Türkiye'de 2001 krizi ile birlikte çok yüksek seviyelere çıkan enflasyon oranlarında, uygulamaya konulan enflasyon hedeflemesi rejimi ile birlikte zaman içerisinde bir düşüş sağlanmıştır. Ancak yine de gerçekleşen enflasyon oranlarının, makul seviyenin üzerinde olduğu ve 2006 yllından beri (2008 küresel krizini takip eden 2009 ve 2010 yllları hariç) enflasyon hedeflerini aştı̆̆1 görülmektedir. Özellikle son ylllarda enflasyon oranlarının tekrardan, bir psikolojik eşik olan çift haneli sayılara çıktı̆̆ izlenmektedir. Dolayisıly Türkiye'de bir enflasyonla mücadele durumu söz konusudur. Öte yandan vergi gelirlerine bakıldığında, dolaylı vergilerin toplam içindeki payının giderek arttığı ve toplam vergi gelirlerinin üçte ikisini geçtiği göze çarpmaktadır. Harcamalar üzerinden alınan dolaylı vergilerin oranlarındaki bir değişimin tüketiciye yansıması nedeniyle, dolaylı vergilerdeki bir artış fiyat artışı olarak algılanabilmektedir. $\mathrm{Bu}$ bağlamda, Türkiye'de enflasyon oranları ve dolaylı vergiler arasında bir ilişkinin olup olmadığının tespit edilmesi, pek çok açıdan yol gösterici olabilecektir.

Çalışmanın amacı, özel tüketim vergisinin (ÖTV) uygulanmaya başlandığı 2003 yılı sonrasında Türkiye'deki enflasyon ve dolaylı vergiler arasındaki nedensellik ilişkisinin araştırılmasıdır. Türkiye'de 1985 yllında katma değer vergisinin (KDV) ve sonrasında ÖTV'nin uygulanmaya başlaması ile birlikte, sonraki yıllarda toplam vergi gelirleri içerisinde dolaylı vergilerin payının giderek artması ve günümüzde bu oranın \%70’lere yaklaşması, enflasyonla ilişkisi bakımından dolaylı vergilerin önemini daha da artırmıştır. Bu kapsamda; uzun yıllardır yüksek enflasyon probleminin yaşandığı Türkiye ekonomisinde, dolaylı vergilerin enflasyonist bir etkiye sahip olup olmadığı, diğer taraftan da enflasyonun dolaylı vergileri ne ölçüde şekillendirdiği araştırılacaktır. Esas olarak bu çalışmanın çıkış noktası, Türkiye'de enflasyonun azaltılmasında bir maliye politikası aracı olarak dolaylı vergilerin etkin olup olmadığının nedensellik testleriyle araştırılmasıdır. Çünkü vergilerin bir araç olarak enflasyonla mücadelede kullanılmasında, daha çok tüketim üzerinden alınan dolaylı vergiler ön plana çıkmaktadır. Mal ve hizmetlerin tamamını kapsayan genel bir tüketim vergisinin, tüketim ve tasarruf arasındaki tercihi tasarruf lehine çevirerek, toplam talebi ve dolayısıyla talep enflasyonunu azaltıcı etkisi gelir vergisine göre daha fazla olacaktır. Bunun nedeni, dolaysız vergilerin tüketimi doğrudan etkilememesi ve gelir vergisinin bir kısmının tasarruflardan ödenmesidir (Susam, 2009, s. 65-66). Ancak diğer taraftan, maliyetleri arttıran ve üreticiler tarafindan genellikle fiyatlar yoluyla tüketiciye yansıtılan dolaylı vergilerin, maliyet enflasyonu açısından enflasyonist bir tarafi da bulunmaktadır (Laufenburger, 1961, s. 250).

Bu bağlamda; çalışmanın temel hipotezi şu şekildedir: "Dolayl vergilerdeki değģ̧im, enflasyon oranndaki değģsimin nedenidir."

Bu hipotez, dolaylı vergilerin enflasyon oranı üzerinde etkisinin bulunduğunu ifade etmekte, ancak bu etkinin yönünü ve hangi faktörlerden kaynaklandığını belirtmemektedir. Bu hipotezin kabul edilmesi durumunda, dolaylı vergilerin enflasyonla mücadelede etkin bir araç olduğu söylenebilecektir. Ancak bu durumda, dolaylı vergilerin enflasyon üzerindeki etkisinin yönünün belirlenmesi büyük önem arz etmektedir. Diğer taraftan; çalışmanın hipotezinin reddedilmesi durumu ise, alternatif üç farklı muhtemel sonucu beraberinde getirmektedir. Bu ihtimaller; enflasyondan dolaylı vergilere doğru tek yönlü bir ilişkinin olması, enflasyon ve dolaylı vergiler arasında çift yönlü bir nedensellik ilişkisinin olması ve bu değişkenler arasında incelenen dönemde herhangi bir nedensellik ilişkisinin olmaması durumlarıdır. Çalışmada kullanılan ve VAR modellerinin tahminine dayanan nedensellik yaklaşımları, bu durumların aynı anda test edilebilmesine imkân tanımaktadır. Bu kapsamda; ilerleyen bölümde enflasyon ile dolaylı vergiler arasındaki ilişkinin teorik altyapısı aktarılacak ve çalşşmanın üçüncü bölümünde konuyla ilgili olan özellikle ampirik çalışmalar özetlenecektir. Çalışmanın dördüncü ve beşinci bölümlerinde ise sırasıyla, kullanılan veri 
setine, uygulanan yöntemlere ve elde edilen bulgulara yer verilecek, devamında bulguların yorumlandığ1 sonuç kısmıyla çalışma sonlandırılacaktır.

\section{Enflasyon ve Dolaylı Vergiler Arasındaki İlişki: Teorik Çerçeve}

Konuyla ilgili teorik ve ampirik çalışmalarda, enflasyon ve dolaylı vergiler arasındaki ilişkinin çift yönlü olabileceği ortaya konulmaktadır (Moździerz, 2017, s. 257). Bir başka deyişle; enflasyondan dolaylı vergilere doğru veya dolaylı vergilerden enflasyona doğru bir nedensellik ilişkisi olabileceği gibi, iki değişken arasında karşılıklı bir nedensellik ilişkisi de bulunabilmektedir. Genel olarak, bu çift yönlü ilişkinin enflasyondan dolaylı vergilere doğru olan kısmını, enflasyonist bir sürecin vergi gelirlerini reel olarak azaltıcı etkisi açıklamaktadır. Buna göre, fiyatlar genel düzeyindeki bir artısın satın alım gücünü düşürmesi, devletin sabit oranlı bir vergiden elde ettiği gelirlerin reel olarak değer kaybetmesine neden olacaktır. Diğer taraftan, dolaylı vergilerin enflasyon üzerindeki etkisi ise, vergi oranlarındaki değişmelerin fiyatları (özellikle de tüketici fiyatlarını) değiştirmesinden kaynaklanmaktadır. Çalışmanın bu bölümünde, enflasyon ile dolaylı vergiler arasındaki ilişkinin her iki boyutu da teorik olarak ele alınmıştır.

Bir ekonomide enflasyonun, diğer pek çok makroekonomik değişken gibi vergi gelirlerini veya genel olarak vergi sistemini de etkilemesi kaçınılmazdır. Enflasyon oranlarının yüksek olduğu ve enflasyon probleminin zaman içerisinde sürekli hale geldiği ekonomilerde, enflasyonun vergiler üzerindeki başlıca etkisi vergi gelirlerini reel olarak aşındırmasıdır. Bir ekonomide enflasyonun, reel vergi gelirlerini arttırması için ise üç koşulun aynı anda gerçekleşmesi gerekmektedir. Bu koşullar; vergiye tabi kazanç ve gelirlerin enflasyon oranına paralel bir şekilde artması, vergiyi doğuran olay ile vergi tahsilatı arasındaki sürenin çok kısa olması ve vergi sisteminin artan oranlı bir tarife yapisına sahip olmasıdır (Mansfield, 1980, s. 31). Genel olarak ise, Özbilen (1997)'de enflasyonun vergi gelirleri ve vergi sistemi üzerindeki genel etkisi şu şekilde özetlenmektedir: Pek çok ülke için en önemli sorunlardan birisi olan enflasyon, tüketici ve üreticileri, tasarruf sahiplerini, borçluları, alacaklıları, mükellefleri, yani genel olarak toplumu çeşitli şekillerde etkileyerek vergi sistemini bozmakta, vergi yükü dağıllımını değiştirmekte ve sonuçta vergilendirme ile hedeflenen ekonomik, mali ve sosyal amaçlardan sapmalara neden olmaktadır (Nowotny, 1980 Akt. Özbilen, 1997, s. 158).

Dolaylı vergiler açısından bakıldığında ise; enflasyonun dolaylı vergiler üzerindeki etkisi temelde, fiyatlar genel düzeyindeki değișikliklerin vergi matrahını etkileyerek vergi gelirlerini de değiștirmesi yoluyla ortaya çıkmaktadır. Fiyatlardaki bir artış, dolaylı vergilerin matrahını yükseltmekte ve vergi mükellefleri daha yüksek vergilerle karşı karşıya kalmaktadır. Dolayısıyla; enflasyonist bir ortamda vergi mükelleflerinin reel vergi yüklerinin artması, reel gelirlerinin azalmasını da beraberinde getirecektir (Güvenek, Alptekin ve Çetinkaya, 2010, s. 3). Bu süreç, diğer gelir gruplarına göre özellikle düşük ve orta gelirlileri çok daha fazla ve olumsuz etkilemektedir. Çünkü, devamlllık gösteren yüksek enflasyon, vergi sistemindeki çeşitli muafiyet ve istisnaları ortadan kaldırmakta, normalde vergilendirilmemesi gereken en küçük gelirlerin de vergi kapsamına girmesine neden olmaktadır. Öte yandan, düşük ve orta gelir gruplarının vergi dilimleri enflasyon nedeniyle daha üst gruplara girmekte, dolayisiyla reel gelirleri artmayan bu kesimin nominal gelirleri arttığından, mevcut gelir seviyesindeki toplam vergi oranları da artmaktadır. Ayrıca, sözü edilen düşük ve orta gelirli kesimin, aynı zamanda tüketim eğilimleri en yüksek olan kesim oldukları ve marjinal tüketim eğilimlerinin genel olarak bire çok yakın olduğu unutulmamalıdır. Bu durumda, harcamalar üzerinden alınan dolaylı vergilerde de benzer şekilde, vergi yükünün çok büyük kısmı tüketim eğilimi fazla olan düşük-orta gelir gruplarında, yani tüketicilerde olacaktır. Çünkü, iktisadi matrah üzerinden belirlenen dolaylı vergilerdeki enflasyondan kaynaklanan matrah artış, tüketicilerin vergi yükünü arttırmaktadır. $\mathrm{Bu}$ durum, enflasyonun, düşük ve orta gelirliler üzerindeki vergi yükünün artmasına neden olduğunu göstermektedir (Özbilen, 1997, s. 159). Diğer yandan; enflasyonun bu şekildeki etkisi, enflasyon oranında beklenenden daha yüksek bir artışın "enflasyon vergisi" olarak da adlandırılan ve bütçe dengesini pozitif etkileyen enflasyon primi ile sonuçlanmasını da sağlamaktadır. Yani bazı iktisatçıların da savunduğu gibi, enflasyonist dönemlerde devlet, yüksek enflasyon ortamından yararlanarak gelir elde etmektedir. $\mathrm{Bu}$ nedenle enflasyona, hükümetin gizli müttefiki de denmektedir (Owsiak, 2017, s. 886). Dolayısıyla, enflasyondaki beklenmedik değişimler, mali gevşemeye veya mali sılkılaştırmaya neden olabilmektedir.

Diğer taraftan; enflasyonun dolaylı vergi gelirleri üzerinde, vergi matrahını arttırması yoluyla ortaya çıkan pozitif etkisinin yanında, toplam talepte neden olduğu değişimlerden kaynaklanan negatif etkisi de bulunmaktadır. Enflasyon nedeniyle satın alım gücünün düşmesi ve beraberinde toplam talepte meydana gelebilecek bir azalma, harcamaları azaltarak harcamalar üzerinden alınan dolaylı vergilerde matrahı düşürecektir. Bu durumda ise dolaylı vergi gelirleri azalacaktır (Güvenek, Alptekin ve Çetinkaya, 2010, s. 
26). Dolayısıyla; dolaylı vergi gelirlerindeki net değişim, fiyat artışlarının, vergi matrahını arttırıcı etkisi ile toplam talepteki azalmanın vergi matrahını azaltıcı etkisinden hangisinin büyük olacağına bağlıdır.

Enflasyon ile vergiler arasındaki ilişkinin incelenmesinde dikkat edilmesi gereken bir diğer önemli nokta, enflasyonun vergi gelirleri üzerindeki etkisinin, vergi türüne göre de değişiklik göstermesidir. Enflasyon, ekonomik faaliyetlerin yapısı açısından tarafsız olmadığından, farklı vergilendirme biçimlerinin devlete sağladığı gelirlerin de farklı olmasına neden olacaktır. Enflasyonun vergi yapısı üzerindeki etkisinin farklılaşması, çeşitli vergi türlerinin fiyat artışları karşısındaki esnekliklerinin birbirinden farklı olmasından kaynaklanmaktadır. Söz konusu esneklik genel olarak gelir vergileri gibi dolaysız vergilerde, dolaylı vergilere göre daha yüksektir. Dolayısıyla; enflasyon oranındaki bir artış, enflasyon primi (ya da enflasyon vergisi) nedeniyle toplam vergi gelirleri içerisinde dolaysız vergilerin payını, dolaylı vergilere göre arttıracaktır. O halde; ülkelerin vergi sistemlerinin yapısındaki önemli farklilıklar, enflasyonun vergiler üzerindeki etkisini de ülkeden ülkeye değiştirecektir. Vergi sistemi daha çok dolaysız vergilere dayanan ve toplam vergi gelirlerinin daha büyük bir kısmını dolaysız vergi gelirlerinin oluşturduğu ülkelerde, enflasyonun vergi gelirleri ve vergilendirme üzerindeki etkisi çok daha önemli olacaktır (Nowotny, 1980, s. 1025-1026). Ancak, Türkiye gibi toplam vergi gelirlerinin daha büyük bir kısmını dolaylı vergi gelirlerinin oluşturduğu ve vergilendirme sisteminde harcamalar üzerinden alınan vergilerin önemli bir yer tuttuğu ülkelerde ${ }^{2}$, enflasyon oranındaki artışın enflasyon vergisi kanalıyla dolaylı vergi gelirlerinde yaratacağı değişim daha sınırlı olacaktır.

Dolaylı vergilerden enflasyona doğru ters yönlü ilişki ise, vergi oranlarındaki değişimlerin fiyatları şekillendirmesinden kaynaklanmaktadır. Modern iktisat teorilerinde ve özellikle piyasa ekonomisinde, devletin (veya hükümetin) fiyatlar üzerinde sınırlı bir etkiye sahip olduğu kabul edilmektedir. Devlet piyasadaki tüketici fiyatlarını, taban fiyat uygulaması ya da tavan fiyat uygulamasi gibi fiyat yönlendirmeleriyle veya mal ve hizmetlerin dolaylı olarak vergilendirilmesi yoluyla etkileyebilmektedir. Bundan hareketle; dolaysız vergilere göre dolaylı vergilerin oranının daha yüksek olduğu bir vergi sisteminin, mali otoritelere fiyatları etkilemesi için birtakım araçlar sağladığı kabul edilmektedir. Dolaylı vergilerin fiyatlar üzerindeki belirleyici etkisi, enflasyona neden olabileceği gibi, enflasyonun yavaşlamasını da sağlayabilmektedir (Moździerz, 2017, s. 257). Dolaylı vergilerin fiyatlar genel düzeyi üzerindeki etkisinin hangi yönde olacağı, içinde bulunulan ekonomik koşullara bağlı olarak değişecektir. Örneğin; ortalama dolaylı vergi oranlarının azaltılması, ekonomide ücret-maliyet sarmalının olduğu varsayıldığında, enflasyonu geçici olarak düşürürken, harcanabilir geliri ve dolayısıyla talebi arttıracaktır (Henry ve Karakitsos, 1986, s. 29). Ancak diğer taraftan, dolaylı vergilerdeki bir değişikliğin kalıcı fiyat değişimlerine ya da enflasyona neden olmayacağını savunanların sayısı da az değildir. Örneğin Woźniak (2002, s. 9-10), dolaylı vergilerden KDV oranlarındaki değişimler nedeniyle fiyatlarda meydana gelecek tek seferlik artışın enflasyon olarak adlandırılamayacağını, çünkü enflasyon tanımının fiyatlardaki herhangi bir artışı değil, uzun vadede kalıcı ve devam eden artısları kapsadığını ifade etmektedir. Quah ve Vahey (1995) ise çekirdek enflasyon kavramından söz ederken, vergi oranlarındaki değişimleri, enflasyonu etkileyen çekirdek dışı faktörlerden birisi olarak ifade etmektedir. Dolayısıyla, enflasyon ile dolaylı vergiler arasındaki ilişkinin bu yönü, günümüzde hala tartsş1lan konulardan birisidir.

Genel olarak vergiler, ekonomideki toplam talep ile beraber toplam arz1 da etkilemektedirler. Vergilerin, kamu ve özel kesim arasındaki kaynak ayırımında etkinliği sağlama fonksiyonu sayesinde toplam talebi azaltması, enflasyonu da azaltıcı bir rol oynamasını beraberinde getirmektedir. Toplam talep açısından durum bu şekildeyken, toplam arz açısından bazı hallerde vergilerin enflasyonist bir etkiye sahip olması kaçınılmazdır. Özellikle üretim maliyetlerini arttıran ve üreticiler tarafından genellikle malın fiyatına eklenen dolaylı vergiler, mal ve hizmetlerin fiyatlarını maliyet enflasyonu açısından arttırmaktadır (Özbilen, 1997, s. 160). Mal ve hizmetlerin satış fiyatlarının artması ve bunun genel fiyat endekslerine de yansıması, satın alım gücü düşen bazı gelir gruplarının ücret artış taleplerine yol açabilecektir. Bu tür talepler, tüketici fiyatları endeksi gibi göstergelerdeki yükselmelere bağlı olabileceği gibi, dolaylı vergi nedeniyle bazı mal ve hizmet fiyatlarındaki artışın yoğun bir şekilde hissedilmesine de bağlı olabilecektir. Böyle bir fiyat-ücret sarmalı ise enflasyonist süreci hızlandıracaktır.

Keynesyen yaklaşıma göre enflasyonun sebebi ekonomideki talep fazlası, söz konusu talep fazlasının nedeni ise kısa vadede üretim düzeyinde bir artışın yaratılamaması, yani arz eksikliğidir. Dolayısıyla, talep

2 T. C. Hazine ve Maliye Bakanlığı tarafından yayımlanan merkezi yönetim bütçe istatistiklerine göre; Türkiye'de toplam vergi gelirleri içerisinde dolaylı vergilerin payı, 2004-2019 döneminde en yüksek \%69,4'e kadar çıkmış (2005 yllında), aynı dönemde bu oran ortalama olarak \%62,7 olarak gerçekleşmiştir. 
fazlasından kaynaklanan enflasyonla mücadelede en etkin yöntemin, maliye politikası araçları olduğu belirtilmektedir. Keynes'e göre, toplam talebin doğrudan ve dolaylı belirleyicisi olan kamu harcamaları ve vergiler, talep fazlasını gidermede en etkili araçlardır. Para politikasının etkinliği ise, likidite tuzağı nedeniyle düşüktür. Kamu harcamalarının kısılması yoluyla doğrudan veya vergi politikası ile özel kesim harcamalarının kısılması yoluyla dolaylı olarak toplam talep değiştirilebilmektedir. Bu bağlamda, Keynesyen iktisatçılar enflasyonla mücadelede daraltıcı maliye politikasının uygulanması gerektiğini savunmaktadırlar (Eken, 2000, s. 14). Vergilerin ekonomik istikrar üzerindeki genel etkisi de, temelde vergilendirme düzeyinin ve yapısının toplam talep üzerindeki etkisi açısından değerlendirilmektedir (Nowotny, 1980, s. 1034). Ancak, kısa dönemde toplam talebin azaltılmasına yönelik olan Keynesyen maliye politikaları, enflasyonun toplam talepteki bir artıstan kaynaklandığı durumda etkili olacaktır. Talep enflasyonu durumunda, devlet vergileri arttırarak ya da kamu harcamalarını azaltarak enflasyonist baskiları kırabilmektedir. Diğer taraftan, enflasyonun üretim yapısı ile talep yapısı arasındaki uyumsuzluktan veya maliyet artışarından kaynaklanması durumunda, maliye politikası araçları ile toplam talebin azaltılması, fiyatlardaki artışı durdurmada yeterli olmayacaktır (Görgün, 1994 Akt: Susam, 2009, s. 64). Bu durumda, dolaylı vergilerin enflasyonla mücadeledeki etkinliği de azalmış ya da tamamen ortadan kalkmış olacaktır. $\mathrm{Bu}$ nedenle, dolaylı vergilerin enflasyon üzerindeki etkisi analiz edilirken, maliyetlerdeki (özellikle de ücretlerdeki) ve vergilerdeki bir artışın üzerinde bir fiyat artışı olduğu, ücretlerin de bir önceki dönemin fiyat düzeyi tarafindan belirlendiği kabul edilmektedir. Böylece, dolaylı vergilerdeki artış, talep koşullarına da bağlı olarak, fiyat-ücret sarmalını harekete geçirerek enflasyona neden olacaktır. Bu süreç, literatürde "vergi kaynaklı enflasyon (tax-push inflation)" kavramı ile ifade edilmektedir (Peacock ve Williamson, 1967, s. 27-45; Brennan ve Auld, 1968, s. 520-525; Pitchford ve Turnovsky, 1975, s. 272-282). Bu kavram, vergilere bağlı olarak fiyatlarda ve ücret düzeyinde meydana gelecek artışların enflasyonist süreci hızlandırdı̆̆1 durumdaki maliyet enflasyonuna vurgu yapmaktadır. Özellikle gelişmekte olan ülkelerde, yüksek talep seviyesinin yönetilebilmesi için alınacak parasal önlemlerin yanında, vergilendirmenin maliyetler üzerindeki arttırıcı etkisi önem kazanmaktadır. Özellikle fiyatlara eklenerek enflasyonu teşvik eden dolaylı vergiler, ödenen vergilerin maliyetlere ilave edilerek fiyatlar yoluyla başkalarına yansıtılması durumu nedeniyle enflasyonist bir süreç (maliyet enflasyonu) ortaya çıkaracaktır (Laufenburger, 1961, s. 250). Dolayısıyla, vergi kaynaklı enflasyonun kısa vadede istikrar politikalarının etkinliği üzerinde önemli etkileri bulunmaktadır. (Nowotny, 1980, s. 1034-1035).

Dolaylı vergilerin, talep enflasyonu ve maliyet enflasyonu gibi iki farklı kanalla fiyatlar genel düzeyini etkilemesi ve bu etkilerin farklı yönlerde olması, dolaylı vergilerle enflasyon arasındaki ilişkinin araştırılmasında tüketici fiyatları ile birlikte alternatif fiyat endekslerinin de kullanılmasını beraberinde getirmiştir. Bu bağlamda; dolaylı vergilerdeki değişikliklerin enflasyona etkisinin araştırılmasında, üretici fiyat endeksi (ÜFE) ve sabit vergi oranlarında uyumlaştırılmış tüketici fiyat endeksi (HICP-CT) gibi iki temel göstergenin kullanıldığı görülmektedir. Bunlardan birincisi olan üretici fiyat endeksi (ÜFE) dolaylı vergileri içermemekte, bu nedenle sadece üreticilerin farklı üretim aşamalarında belirlediği fiyat değişikliklerini yansıtmaktadır. Üretici fiyat endeksinin alternatif bir enflasyon ölçüsü olarak sağladığı birtakım avantajlar nedeniyle bazı ekonomistler, doğrudan enflasyon hedeflemesi stratejisi uygulayan ülkelerde enflasyonla mücadele politikalarının bu göstergeye dayandırılmasını önermektedirler (Ciżkowicz, 2012, s. 2). Avrupa İstatistik Ofisi (Eurostat) tarafindan kullanılan sabit vergi oranlarında uyumlaştırlmış tüketici fiyat endeksi (HICP-CT) ise, fiyatları etkileyen bir faktör olarak dolaylı vergi oranlarındaki değişikliklerin etkisini incelemek için önemli göstergelerden biri olarak kabul edilmektedir. HICP-CT, vergi oranlarındaki değișikliklerin etkisini hariç tutarak, belirli bir dönemde tüketici mal ve hizmet fiyatlarındaki değişimleri ölçen bir oran olarak tanımlanmaktadır. Ayrıca, HICP-CT’nin hesaplama prensipleri tüm AB ülkelerinde standartlaştırılmıştır ve ülkeler arasında karşılaştırma yapılabilmesine de imkân sağlamaktadır (Moździerz, 2017, s. 258).

\section{Ampirik Literatür}

Enflasyon ve vergilendirme ilişkisi hakkındaki literatürün önemli bir kısmı, enflasyonun vergi politikaları üzerindeki etkilerine yoğunlaşmakta, vergilendirmenin enflasyon üzerindeki etkileri daha az sayıdaki çalışmada ele alınmaktadır. Diğer yandan enflasyon-vergi gelirleri ilişkisini inceleyen çalışmaların genel olarak, enflasyonun vergi gelirlerini ne şekilde ve ne ölçüde etkilediğini araştırdığı, bu noktada da özellikle gelir vergisi gibi dolaysız vergileri ele aldıkları görülmektedir. Dolaylı vergiler ile enflasyon ilişkisinin incelendiği çalş̧malardan birisi olan Koutsouvelis ve Papastathopoulos (2013), Yunanistan ekonomisi için dolaylı vergiler ile enflasyon arasındaki ilişkiyi doğrusal regresyon modeliyle incelemişler ve dolaylı vergilerin enflasyonu arttırdığı sonucuna ulaşmışardır. Moździerz (2017) ise, 2007-2016 dönemi ve 
seçilmiş ülkeler kapsamında yaptı̆̆ çalışmasında, dolaylı vergiler ve enflasyon arasındaki ilişkinin çift yönlü olduğunu tespit etmiştir. Elde ettiğgi bulgulara göre; dolaylı vergilerin fiyatları etkilemesi sebebiyle enflasyon oranında bir artışa neden olduğu ve enflasyonla mücadele için dolaylı vergi oranlarının azaltılması gerektiğini ifade etmektedir. Diğer yandan, fiyatlardaki değişikliklerin vergi matrahını değiştirmesi yoluyla dolaylı vergi gelirlerini de etkilediğini ileri sürmektedir. Elkina (2019) ise çalş̧masında; 2004 yllında Rusya'da katma değer vergisi oranının düşürülmesi ve satış vergisinin kaldırılmasının, tüketici fiyatları (ya da tüketici enflasyonu) üzerindeki etkisini analiz etmiştir. Sonuçlar, düşük oranlar olduğunda dolaylı vergilerin fiyatlara aktarılma etkisinin düşük olduğunu göstermiştir. Ayrıca, dolaylı vergi oranlarını düşürmenin tüketici fiyatlarını çok fazla etkilemediği, bu durumdan mal üreticilerinin ve satıcılarının daha çok fayda sağladığ ifade edilmektedir.

Konuyla ilgili Türkiye ekonomisi için yapılmış az sayıdaki çalışmaya bakıldı̆̆ında ise, çalışmaların kapsamı ve ulaşılan sonuçlar aşağıdaki gibi özetlenmiştir:

Akıncı ve Özçelik (2018) çalışmalarında, 2006-2018 dönemi için Türkiye'de dolaylı vergiler ile enflasyon arasındaki ilişkiyi incelerken, dolaylı vergilerin enflasyon üzerindeki etkisine yoğunlaşmışlardır. Çalışmada, dolaylı vergiler ile enflasyon arasında uzun dönemli ilişki olduğu, dolaylı vergilerdeki bir artışın enflasyonu arttırdığ1 ve enflasyonla mücadelede dolaylı vergilerin etkin bir rol oynadığ1 sonucuna ulaşmışlardır.

Çakmaklı, Demiralp, Yeşiltaş ve Yıldırım (2018), Türkiye'de 2005-2017 döneminde tütün ürünlerine uygulanan dolaylı vergilerin enflasyon üzerindeki etkilerini inceledikleri çalışmalarında, tütün mamullerine uygulanan dolaylı vergilerdeki bir artışın enflasyonu arttırdığı ve bu etkinin kısa vadede ortaya çıktığı sonucuna ulaşmışlardır.

Arısoy ve Ünlükaplan (2011), katma değer vergisinin gelişimine ve önemine dikkat çektikleri çalışmalarında, 1994-2010 dönemi için Türkiye'de KDV oranı, KDV geliri, kamu harcamaları ve enflasyon oranı arasındaki ilişkileri VAR modelleri yardımıyla incelemişlerdir. Elde ettikleri sonuçlardan birisi de, KDV gelirlerinin enflasyonist bir etkiye sahip olduğuna işaret etmektedir.

Güvenek, Alptekin ve Çetinkaya (2010) çalışmalarında, Türkiye'de 1980-2008 dönemi için enflasyon ve dolaylı vergiler arasındaki ilişkiyi VAR modeli yardımıyla analiz etmişlerdir. Elde ettikleri bulgular, tüketici fiyatları endeksi ile dolaylı vergi gelirleri arasında çift yönlü bir ilişki olduğunu göstermektedir.

Karadağ ve Westaway (1999), Türkiye'de katma değer vergisi oranlarındaki bir artışın pek çok sektörde tüketici fiyatlarını arttırdığı ve bunun söz konusu sektörlerde üretimde de bir azalmaya neden olduğu sonucuna ulaşmışlardır.

\section{Veri}

Türkiye'de enflasyon ve dolaylı vergiler arasındaki ilişkinin incelendiği bu çalışmada 2004:01-2019:12 dönemi aylık verileri kullanılmıştır. Analiz edilen dönem ile ilgili kısıtlar şu şekildedir: i) Dolaylı vergilerin içerisinde önemli bir paya sahip olan özel tüketim vergisinin (ÖTV) 2002 yll Ağustos ayında uygulanmaya başlanmasi; ii) 2006 yllinda uluslararası standartlara uyum sağlamak için konsolide bütçeden merkezi yönetim bütçesine geçilmesi ve yayımlanan merkezi yönetim bütçe istatistiklerinin 2004 yll Ocak ayından başlaması.

Bu doğrultuda, dolaylı vergi gelirleri değişkenine ilişkin veriler, T. C. Hazine ve Maliye Bakanlı̆̆ internet sitesinde yayımlanan merkezi yönetim bütçe istatistiklerinden faydalanılarak ve Avrupa Komisyonu tarafindan kullanilan metodolojide kabul edilen dolaylı vergi tanımı kullanılarak oluşturulmuştur. Söz konusu tanıma göre, dolaylı vergiler; KDV, harcamalar üzerinden alınan tüketim vergileri, ithalat ile ilgili vergiler, ürünler üzerinde uygulanan diğer vergiler ve üretimdeki diğer vergileri içeren üretim ve ithalat vergileridir (European Commission, 2016, s. 296). Diğer yandan; harcamalar üzerinden alınan dolaylı vergilerin yapısı ve verginin yansıması dikkate alınırsa, örneğin fiyatlardaki bir artış, nominal olarak dolaylı vergi gelirlerini de arttıracaktır. Dolayısıyla; enflasyonun dolaylı vergiler üzerinde bu şekildeki etkisi, bu iki değişken arasındaki ilişkinin gerçek yönünün ve ilişkiyi açıklayan dinamiklerin belirlenmesini engelleyebilecektir. Bu sebeple; merkezi yönetim bütçe istatistiklerinden elde edilen ve cari fiyatlarla ifade edilmiş olan dolaylı vergi gelirleri serisi, 2003 yllı bazlı tüketici fiyat endeksi (TÜFE, $2003=100$ ) ile reel hale getirilerek enflasyon etkilerinden arındırılmıştır. Bu sayede, dolaylı vergi gelirlerinde reel anlamdaki bir değişim, fiyatlar dişındaki diğer değişkenler tarafından (örneğin dolaylı vergi 
oranlarındaki bir değişim ya da talebin ve tüketim harcamalarının değişmesiyle tahsil edilen harcama vergisi miktarının değişmesi gibi) açıklanabilecektir.

Diğer yandan; analizde, Yurt İçi Üretici Fiyat Endeksi (ÜFE) (2003=100) ve Tüketici Fiyat Endeksi (TÜFE) $(2003=100)$ olmak üzere iki farklı enflasyon göstergesi kullanılmış, dolaylı vergi gelirleri ile ÜFE ve TÜFE arasındaki ilisski ayrı ayrı incelenmiştir. Veriler, Türkiye İstatistik Kurumu'nun (TÜIK) internet sayfasından alınmıştır. Dolaylı vergilerden enflasyona doğru olan bir ilişki iki açıdan değerlendirilebilmektedir. Bunlardan birincisi; dolaylı vergilerin fiyatlar üzerindeki etkisinin, maliyet enflasyonunu tetikleyerek vergi kaynaklı enflasyona neden olmasıdır. Bu nedenle, analizin ilk bölümünde enflasyon göstergesi olarak, maliyetlerin fiyatlara etkisini iyi bir şekilde yansıtan ve dolaylı vergileri içermeyen ÜFE kullanılmıştır. Bu sayede, yaşanan enflasyonist süreçte dolaylı vergilerden kaynaklanan maliyet enflasyonunun etkisi araştırlacaktır. İkinci olarak ise; dolaylı vergilerdeki bir değişim tüketici fiyatlarını etkileyerek, doğrudan olmasa da tüketim harcamalarını ve toplam talebi değiștirebilmektedir. Bu durumda ise, Keynesyen maliye politikası yaklaşımında belirtildiği gibi, enflasyonu azaltmak için dolaylı vergiler bir araç olarak kullanılabileceklerdir. Dolaylı vergiler ve enflasyon arasındaki ilişkinin, toplam talepteki değişimi temel alan bu yönü ise, TÜFE değişkeni ile araştırılmıştır.

Serilere ARIMA (X-12) yöntemi kullanılarak mevsimsel düzeltme işlemi uygulanmıştır. Farklı yöntemler arasından ARIMA (X-12) yönteminin seçilme nedeni, Ongan (2002)'de Türkiye'de fiyat endekslerine mevsimsel düzeltme işleminin uygulanmasında belirtilen yöntemin daha uygun olduğunun tespit edilmesidir. Diğer taraftan, serilerdeki muhtemel değişen varyans problemini ve boyutsal farkllikları ortadan kaldırmak için, her bir değişkene ait serinin doğal logaritması alınmıştır. Çalışmanın ilerleyen kısımlarında; logaritmik dönüşüm uygulanmış dolaylı vergi gelirleri değişkeni $\mathrm{V}_{\mathrm{t}}$, enflasyon değişkenine ilişkin üretici fiyat endeksi ÜFE $E_{t}$ ve tüketici fiyat endeksi $\mathrm{TÜFE}_{\mathrm{t}}$ notasyonları ile gösterilmiştir.

\section{Yöntem ve Bulgular}

Türkiye'de enflasyon ile dolaylı vergiler arasındaki nedensellik ilişkisinin incelenmesine yönelik analizin ilk aşamasında, değişkenlere ait serilerin stokastik özelliklerini belirlemek amacıyla standart birim kök testleri uygulanmıștır. Bu doğrultuda gerçekleştirilen ADF (Dickey ve Fuller, 1981), PP (Phillips ve Perron, 1988) ve KPSS (Kwiatkowski, Phillips, Schmidt ve Shin, 1992) birim kök testleri sonuçları Tablo 1 'de gösterilmiştir.

Tablo 1. Birim Kök Testi Sonuclar

\begin{tabular}{|c|c|c|c|}
\hline & $A D F$ & $P P$ & KPSS \\
\hline $\mathrm{V}_{\mathrm{t}}$ & $-3,17^{c}(14)$ & $-8,57^{a}(7)$ & $0,139 \mathrm{~b}(9)$ \\
\hline $\mathrm{UFE}_{\mathrm{t}}$ & $-0,095(2)$ & $-0,85(1)$ & $1,63(11)$ \\
\hline TUFE $_{t}$ & $0,38(4)$ & $0,01(11)$ & $0,252(10)$ \\
\hline$\Delta \mathrm{UFE}_{\mathrm{t}}$ & $-9,33^{a}(1)$ & $-7,71^{a}(8)$ & $0,148^{a}(0)$ \\
\hline$\Delta \mathrm{TUFE}_{\mathrm{t}}$ & $-8,61^{a}(3)$ & $-10,38^{a}(19)$ & $0,149^{a}(12)$ \\
\hline \multicolumn{4}{|c|}{$\begin{array}{l}\text { a, b ve }{ }^{\mathrm{c}} \text { sırasıyla } \% 1, \% 5 \text { ve } \% 10 \text { önem düzeyinde istatistiksel olarak anlamlı olduğunu göstermektedir. Birim kök testlerinde her } \\
\text { üç değişken için, serilerin zaman yolu grafiklerine bakarak "Trendli-Sabitli” model kullanılmıştır. ADF testinde optimal } \\
\text { gecikme uzunlukları, maksimum gecikme uzunluğu } 14 \text { alınarak Schwarz Bilgi Kriteri (SIC)'ne göre belirlenmiştir. PP ve KPSS } \\
\text { testlerinde ise band genișliği Newey-West metodu ile belirlenmiștir. }\end{array}$} \\
\hline
\end{tabular}

Birim kök testleri sonuçlarına bakıldığında; $\mathrm{UFE}_{\mathrm{t}}$ ve $\mathrm{TUFE}_{\mathrm{t}}$ değişkenlerinin, ADF, PP ve KPSS birim kök testlerine göre düzeyde durağan olmadığı ve birinci fark1 alındıktan sonra durağan hale geldiği, $\mathrm{V}_{\mathrm{t}}$ değişkeninin ise düzey değerinin durağan olduğu görülmektedir. Sonuç olarak; enflasyon göstergelerine ilişkin değişkenlerin fark durağan olduğu ve birinci dereceden bütünleşik olduğu ( I(1)), diğer yandan dolaylı vergi gelirlerinin trend durağan olduğu $(\mathrm{I}(0))$ bulgusuna ulaşılmıştır. Dolayısıyla; Asteriou ve Hall (2007)'de ifade edildiği gibi, farklı mertebelerde durağan olan ya da aralarında eşbütünleşme olmayan seriler arasındaki ilişki, serilerin durağan formlarıyla oluşturulan VAR modelleri yardımıyla analiz edilmektedir. Bu kapsamda, değişkenler arasındaki nedensellik ilişkisi, Granger nedensellik testi ve TodaYamamoto (1995) yaklaşımına dayalı Granger nedensellik testi ile araştırılmıştır.

VAR modeline dayalı Granger nedensellik testi, iki değişken arasında nedenselliğin yönünü belirlemek için kullanılmakta ve değişkenler arasında eşbütünleşme ilişkisinin olmadığ1 durumda durağan serilere uygulanabilmektedir. Buna göre; $\mathrm{UFE}_{\mathrm{t}}$ ve TUFE değişkenleri için ayrı ayrı oluşturulan ve bu değişkenlerin durağan biçimlerinin $\left(\Delta \mathrm{UFE}_{\mathrm{t}}\right.$ ve $\Delta \mathrm{TUFE}_{\mathrm{t}}$ ) yer aldığ $\mathrm{VAR}$ modelleri şu şekildedir: 
$\Delta U F E_{t}=\alpha_{0}+\sum_{i=1}^{p} \alpha_{1 i} \Delta U F E_{t-i}+\sum_{i=1}^{p} \alpha_{2 i} V_{t-i}+\varepsilon_{1 t}$

$V_{t}=\beta_{0}+\sum_{i=1}^{p} \beta_{1 i} V_{t-i}+\sum_{i=1}^{p} \beta_{2 i} \Delta U F E_{t-i}+\varepsilon_{2 t}$

$\Delta T U F E_{t}=\alpha_{0}+\sum_{i=1}^{k} \alpha_{1 i} \Delta T U F E_{t-i}+\sum_{i=1}^{k} \alpha_{2 i} V_{t-i}+\varepsilon_{1 t}$

$V_{t}=\beta_{0}+\sum_{i=1}^{k} \beta_{1 i} V_{t-i}+\sum_{i=1}^{k} \beta_{2 i} \Delta T U F E_{t-i}+\varepsilon_{2 t}$

Yukarıdaki denklemlerde p ve k, değişkenlerle tahmin edilen standart VAR modelinin bilgi kriterleri ile belirlenen gecikme uzunluğudur. Schwarz (SIC) bilgi kriterine göre Denklem (1) ve Denklem (2)'den oluşan sistem için belirlenen optimal gecikme uzunluğu $p=2$ iken, Denklem (3) ve Denklem (4) için belirlenen optimal gecikme uzunluğu $\mathrm{k}=4$ 'tür. Belirlenen gecikme uzunluklarıyla oluşturulan VAR modellerinin durağanlık ve kararlılık koşullarını sağladığı ve hata terimlerinin otokorelasyonsuz olduğu da tespit edilmiştir. Granger nedensellik testinde, modelde yer alan bağımsız değişkenin gecikmeli değerlerinin katsayılarının, grup halinde sıfıra eşit olup olmadığı F-istatistiği ile test edilmektedir. Buna göre; dolaylı vergilerin $\left(\mathrm{V}_{\mathrm{t}}\right)$, üretici fiyat endeksinin $\left(\mathrm{UFE}_{\mathrm{t}}\right)$ nedeni olup olmadığı, Denklem (1)'in tahmininden " $\mathrm{H}_{0}: \alpha_{21}=\alpha_{22}=0$ " temel hipotezinin F-istatistiği ile testinin sonucuna bağllyken; üretici fiyat endeksinin $\left(\mathrm{UFE}_{\mathrm{t}}\right)$, dolaylı vergilerin $\left(\mathrm{V}_{\mathrm{t}}\right)$ nedeni olup olmadığ 1 ise, Denklem (2)'nin tahmininden " $\mathrm{H}_{0}: \beta_{21}=\beta_{22}=0$ " temel hipotezinin F-istatistiği ile testinin sonucuna bağlıdır. Benzer şekilde; dolaylı vergilerin $\left(\mathrm{V}_{\mathrm{t}}\right)$, tüketici fiyat endeksinin $\left(\mathrm{TUFE}_{\mathrm{t}}\right.$ ) nedeni olup olmadığ1, Denklem (3)'ün tahmininden " $\mathrm{H}_{0}: \alpha_{21}=\alpha_{22}=\alpha_{23}=\alpha_{24}=0$ " temel hipotezinin F-istatistiği ile testinin sonucuna bağllyken; tüketici fiyat endeksinin (TUFE $E_{\mathrm{t}}$ ), dolaylı vergilerin $\left(\mathrm{V}_{\mathrm{t}}\right)$ nedeni olup olmadığ ise, Denklem (4)'ün tahmininden " $\mathrm{H}_{0}: \beta_{21}=\beta_{22}=\beta_{23}=\beta_{24}=0$ " temel hipotezinin F-istatistiği ile testinin sonucuna bağlıdır. $\mathrm{Bu}$ doğrultuda, değişkenlerin durağan halleriyle oluşturulan VAR modellerinin tahminine dayalı olarak uygulanan Granger nedensellik testi sonuçları Tablo 2'de verilmiştir.

Tablo 2. Granger Nedensellik Testi Sonuclar

\begin{tabular}{|c|c|c|c|c|}
\hline \multicolumn{2}{|c|}{ Temel Hipotez } & \multirow{2}{*}{$\frac{\text { Gecikme Uzunluğu }}{2}$} & \multirow{2}{*}{$\frac{F \text {-istatistiği }}{2,4571}$} & \multirow{2}{*}{$\frac{\text { Olasılik Değeri }}{0,2927}$} \\
\hline & $\Longrightarrow \Delta \mathrm{UFE}_{\mathrm{t}}$ & & & \\
\hline$\Delta \mathrm{UFE}_{\mathrm{t}}$ & $\Longrightarrow V_{t}$ & 2 & 2,0751 & 0,3543 \\
\hline & $\Longrightarrow \Delta \mathrm{TUFE}_{\mathrm{t}}$ & 4 & $9,7797 \mathrm{~b}$ & 0,0443 \\
\hline$\Delta \mathrm{TUFE}_{\mathrm{t}}$ & $\Longrightarrow \mathrm{V}_{\mathrm{t}}$ & 4 & $15,1078^{a}$ & 0,0045 \\
\hline
\end{tabular}

Tablo 2'deki test sonuçlarına göre; dolaylı vergi gelirleri ile üretici fiyat endeksi değişkenleri arasında herhangi bir nedensellik ilişkisi tespit edilememiştir. Diğer taraftan; " $\mathrm{V}_{\mathrm{t}}$, TUFE $\mathrm{t}_{\mathrm{t}}$ nin Granger nedeni değildir" temel hipotezi $\% 5$ anlamlllk düzeyinde ve "TUFE $E_{t}, V_{t}$ 'nin Granger nedeni değildir" temel hipotezi $\% 1$ anlamll1ık düzeyinde reddedilmektedir. Dolayısıyla; Granger nedensellik testi sonucuna göre, dolaylı vergi gelirleri ve tüketici fiyat endeksi arasındaki nedensellik ilişkisinin çift yönlü olduğu görülmektedir.

Diğer taraftan; Yavuz (2006)'un çalışması göz önünde bulundurularak, Granger nedensellik testi sonuçlarının dayanıklı (robust) olabilmesi ve sağlıklı yorumlanabilmesi için, söz konusu değişkenler arasındaki nedensellik ilişkisi Toda ve Yamamoto (1995) yaklaşımı ile de test edilecektir. VAR modellerinin tahminine dayanan ve genellikle F testinin kullanıldığı Granger nedenselliğinden farklı olarak, TodaYamamoto yaklaşımında dönüştürülmüş Wald testi kullanılmaktadır. Çünkü Toda ve Yamamoto (1995), serilerin durağan olmaması halinde geleneksel F-istatistiğinin standart dağılıma sahip olmayacağını ve bu nedenle F testinin sonucunun geçerli olmayabileceğini göstermişlerdir. Yine aynı çalışmada, durağan olmasalar bile serilerin düzey değerlerinin yer aldığı VAR modelinin tahmin edilerek standart Wald testinin uygulanabileceği belirtilmektedir. Toda-Yamamoto yaklaşımının önemli özelliklerinden bir diğeri de, birim kök ve eşbütünleşme özelliklerinin belirlenmesinde kullanılan potansiyel eğilimli ön testlere gerek duymamasıdır. Bu sayede, serilerin bütünleşme derecesinin yanlış tespit edilmesi durumundaki risk de en 
aza indirilmektedir (Yavuz, 2006, s. 169). Dolayısıyla, serilerin düzey değerleri ile oluşturulmuş VAR modelinin tahminine uygulanan standart Wald testine dayanan Toda-Yamamoto nedensellik testi, değişkenlerin bütünleşme dereceleri ve eşbütünleşme özelliklerini dikkate almamaktadır. Bu kapsamda; yine iki ayrı VAR modeli tahmin edilmiş, birinci model $U_{F E} v_{t} V_{t}$ değişkenleri ile oluşturulurken, ikinci modelde TUFE $_{t}$ ve $V_{t}$ değişkenleri yer almıştır. Toda-Yamamoto testinin uygulanacağı VAR sistemi aşağıldaki gibidir:

$$
\begin{aligned}
& U F E_{t}=\alpha_{0}+\sum_{i=1}^{k} \alpha_{1 i} U F E_{t-i}+\sum_{j=k+1}^{d_{\max }} \alpha_{2 j} U F E_{t-j}+\sum_{i=1}^{k} \beta_{1 i} V_{t-i}+\sum_{j=k+1}^{d_{\max }} \beta_{2 j} V_{t-j}+\lambda_{1 t} \\
& V_{t}=\varphi_{0}+\sum_{i=1}^{k} \varphi_{1 i} U F E_{t-i}+\sum_{j=k+1}^{d_{\max }} \varphi_{2 j} U F E_{t-j}+\sum_{i=1}^{k} \delta_{1 i} V_{t-i}+\sum_{j=k+1}^{d_{\max }} \delta_{2 j} V_{t-j}+\lambda_{2 t} \\
& T U F E_{t}=\alpha_{0}+\sum_{i=1}^{k} \alpha_{1 i} T U F E_{t-i}+\sum_{j=k+1}^{d_{\max }} \alpha_{2 j} T U F E_{t-j}+\sum_{i=1}^{k} \beta_{1 i} V_{t-i}+\sum_{j=k+1}^{d_{\max }} \beta_{2 j} V_{t-j}+\lambda_{1 t} \\
& V_{t}=\varphi_{0}+\sum_{i=1}^{k} \varphi_{1 i} T U F E_{t-i}+\sum_{j=k+1}^{d_{\max }} \varphi_{2 j} T U F E_{t-j}+\sum_{i=1}^{k} \delta_{1 i} V_{t-i}+\sum_{j=k+1}^{d_{\max }} \delta_{2 j} V_{t-j}+\lambda_{2 t}
\end{aligned}
$$

Yukarıdaki modellerden Denklem (5) ve Denklem (6), UFE $\mathrm{t}_{\mathrm{t}}$ değişkeni ile $\mathrm{V}_{\mathrm{t}}$ değişkeni arasındaki nedensellik ilişkisinin araştırılmasında, Denklem (7) ve Denklem (8) ise, TUFE $t_{t}$ değisşkeni ile $V_{t}$ değisskeni arasındaki nedensellik ilişkisinin araştırılmasında kullanılmıştır. Bu modellerde; k, VAR sisteminin bilgi kriterleri tarafindan belirlenen uygun gecikme uzunluğunu, $d_{\max }$ ise modeldeki değişkenlerin maksimum bütünleşme derecesini ifade etmektedir. $\mathrm{Bu}$ yöntemde; $\left(\mathrm{k}+\mathrm{d}_{\max }\right)$ gecikmeli bir VAR modeli tahmin edilmekte, daha sonra bu denklemlerin her birindeki bağımsız değişkenin ilk $\mathrm{k}$ gecikmesine ayrı ayrı Wald testi uygulanmaktadır. Dolayısıyla; Toda-Yamamoto yaklaşımının birinci aşaması modeldeki değişkenlerin bütünleşme derecelerinin belirlenmesi, ikinci aşaması ise VAR sisteminin tahmini ve Wald testinin uygulanmasıdır. Buna göre; Denklem (5)'deki $\beta_{1 i}$ parametresinin anlamlı şekilde sıfirdan farklı olması durumunda $V_{t}$ değişkeni $\mathrm{UFE}_{\mathrm{t}}$ değişkeninin nedenidir ve Denklem (7)'deki $\beta_{1 i}$ parametresinin anlamlı şekilde sıfırdan farklı olması durumunda $V_{t}$ değişkeni TUFE $_{t}$ değişkeninin nedenidir sonucuna ulaşılabilecektir. Diğer yandan; Denklem (6)'da ve Denklem (8)'de yer alan $\varphi_{1 i}$ parametresinin anlamlı şekilde sıfırdan farklı olması durumunda da, sırasıyla $U_{F E}$ ve TUFE $_{t}$ değişkenlerinin $V_{t}{ }_{t}$ nin nedeni olduğu sonucuna ulaşlacaktır.

Bu doğrultuda; VAR modellerinin optimal gecikme uzunlukları (k), Schwarz (SC) bilgi kriterine göre, Denklem (5) ve Denklem (6) için 2 olarak belirlenirken, Denklem (7) ve Denklem (8) için 4 olarak belirlenmiştir. Belirlenen bu gecikme uzunluklarıyla oluşturulan VAR modellerinin durağanlık ve kararlılık koşullarını sağladığı ve hata terimlerinin otokorelasyonsuz olduğu teyit edilmiştir. Toda-Yamamoto yaklaşımının prensiplerine göre bu gecikmelere, modellerdeki değişkenlerin maksimum bütünleşme derecesi $\left(\mathrm{d}_{\max }\right)$ olan 1 eklenmiştir. Daha sonra, $\mathrm{UFE}_{\mathrm{t}}$ ve $\mathrm{V}_{\mathrm{t}}$ değişkenlerinin düzey değerleriyle oluşturulmuş 3 gecikmeli VAR modeli ile TUFE $_{t}$ ve $V_{t}$ değişskenlerinin düzey değerleriyle oluşturulmuş 5 gecikmeli VAR modelleri, görünürde ilişkisiz regresyon (SUR) kullanılarak tahmin edilmiştir. Tahmin edilen bu VAR modellerine dayanarak gerçekleştirilen Toda-Yamamoto nedensellik testine ilişkin bulgular Tablo 3'de sunulmuştur.

Toda-Yamamoto nedensellik testi sonuçlanı incelendiğinde, sadece “ $T U F E_{t}, V_{t}$ 'nin Granger nedeni değildir" temel hipotezinin \%1 anlamlılık düzeyinde reddedildiği, diğer hipotezlere ilişkin istatistiklerin ise anlamsız olduğu görülmektedir. Bu durumda; tüketici fiyat endeksinden dolaylı vergi gelirlerine doğru tek yönlü bir nedensellik ilişkisi olduğu, üretici fiyat endeksi ile dolaylı vergi gelirleri arasında herhangi bir nedensellik ilişkisinin bulunmadığı sonucuna ulaşılmıştır. 
Tablo 3. Toda-Yamamoto Nedensellik. Testi Sonuçar

\begin{tabular}{|c|c|c|c|c|c|}
\hline \multicolumn{3}{|c|}{ Temel Hipotez } & \multirow{2}{*}{$\begin{array}{c}\begin{array}{c}\text { Gecikme Uzunluğu } \\
\left(\boldsymbol{k}+d_{\max }\right)\end{array} \\
3\end{array}$} & \multirow{2}{*}{$\frac{\text { Wald İstatistiği }}{0,0611}$} & \multirow{2}{*}{$\frac{\text { Olasılık Değeri }}{0,9699}$} \\
\hline$\overline{V_{t}}$ & $\Longrightarrow$ & $\mathrm{UFE}_{\mathrm{t}}$ & & & \\
\hline $\mathrm{UFE}_{\mathrm{t}}$ & $\Longrightarrow$ & $V_{t}$ & 3 & 1,5619 & 0,4580 \\
\hline$V_{t}$ & $\Rightarrow$ & TUFE $_{t}$ & 5 & 2,9526 & 0,5658 \\
\hline TUFE $_{t}$ & $\Rightarrow$ & $V_{t}$ & 5 & $18,0224^{a}$ & 0,0012 \\
\hline
\end{tabular}

Granger nedensellik testi ile Toda-Yamamoto nedensellik testinin ortak sonuçları şu şekildedir: i) $\mathrm{UFE}_{t}$ ve $V_{t}$ değişkenleri arasında nedensellik ilişkisi yoktur. ii) TUFE ${ }_{t}$ değişkeni, $V_{t}$ değisskeninin nedenidir.

Bu bağlamda, TUFE $_{t}$ ve $V_{t}$ değişkenleri arasındaki bu sonucu desteklemek ve TUFE $E_{t}$ değişkeninden $\mathrm{V}_{\mathrm{t}}$ değişkenine doğru belirlenen tek yönlü ilişkinin işaretini tespit etmek amacıyla, Toda-Yamamoto yaklaşımı gibi değişkenlerin durağanlık özelliklerini dikkate almayan Pesaran, Shin ve Smith (2001) tarafindan geliştirilmiş sınır testi uygulanmıştır.

Kısıtlanmamış hata düzeltme modelinin tahminine dayanan sınır testi yönteminin, Engle-Granger (1987) veya Johansen (1988) gibi eşbütünleşme yaklaşımlarına göre avantajları; değiş̧kenlerin aynı mertebeden durağan olma koşulunun olmaması, daha iyi istatistiksel özelliklere sahip olması ve küçük örneklerde daha güvenilir sonuçlar vermesi şeklinde belirtilmektedir (Narayan ve Narayan, 2005: 429). Sınır testinde kullanılacak olan ve nedensellik testleri sonucunda elde edilen ilişkinin yönüne göre $V_{t}$ 'nin bağımlı değişken olduğu kısıtsız hata düzeltme modeli aşağıdaki gibidir:

$\Delta V_{t}=\alpha_{0}+\alpha_{1} @$ trend $+\sum_{i=1}^{p} \alpha_{2 i} \Delta V_{t-i}+\sum_{j=0}^{p} \alpha_{3 i} \Delta T U F E_{t-j}+\delta_{1} V_{t-1}+\delta_{2} T U F E_{t-1}+\mu_{t}$

Sınır testinin ilk aşamasında, yukarıda yer alan Denklem (9) tahmin edilecektir. Burada en önemli noktalardan birisi yine, uygun gecikme uzunluğunun bilgi kriterlerinden faydalanılarak seçilmesidir. Aynı zamanda, gecikme uzunluğu belirlenirken, seçilen gecikme uzunluğunda hata terimleri arasında otokorelasyonun bulunmamasına da dikkate edilmelidir (Kıran ve Güriş, 2011: 72). Bu bağlamda, Schwarz (SC) bilgi kriterine göre belirlenen ve sınır testinin uygulanacağı ARDL $(1,0)$ modeli tahmin sonuçları Tablo 4'de sunulmuştur.

Tablo 4. ARDL(1,0) Modeli Tabmin Sonuclar

\begin{tabular}{|c|c|c|c|}
\hline & Katsay1 & Standart Hata & t-istatistiğ \\
\hline$\overline{V_{t-1}}$ & $0,3310^{a}$ & 0,0672 & 4,9206 \\
\hline TUFE $_{t}$ & $-1,1454^{a}$ & 0,2301 & $-4,9771$ \\
\hline c & $12,5290^{\mathrm{a}}$ & 1,5488 & 8,0891 \\
\hline @ trend & $0,0101^{a}$ & 0,0017 & 5,8531 \\
\hline \multicolumn{4}{|c|}{$\mathrm{R}^{2}=0,7683 ;$ Adj-R $\mathrm{R}^{2}=0,7646 ; F$-ist. $=206,74 ; F$-ist $(p)=0,000 ; D W=2,0907$} \\
\hline
\end{tabular}

Tahmin edilen ARDL $(1,0)$ modelinin tanısal test sonuçları modelin temel varsayımları sağladığını göstermektedir. Diğer taraftan, tahmin edilen parametrelerin istikrarlı olup olmadığını belirlemek amacıyla, Brown, Durbin ve Evans (1975) tarafindan önerilen "CUSUM" ve "CUSUM of Squares" testleri uygulanmış, test sonuçları Şekil 1'de gösterilmiştir. Buna göre, CUSUM ve CUSUM of Squares test istatistiklerinin \%95 güven aralığ1 içerisinde olduğu ve tahmin edilen parametrelerin istikrarlı olduğu görülmektedir. 

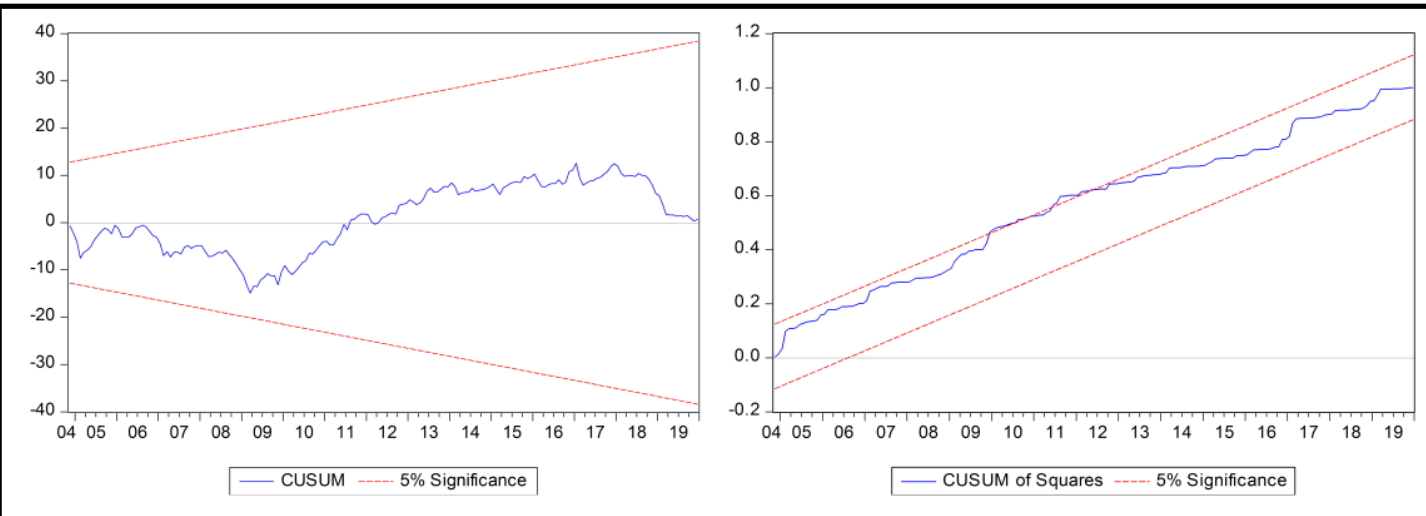

Şekil 1. ARDL(1,0) Modeli Tabmini İ̧in CUSUM ve CUSUM-SQ Testi Grafikleri

Dolaylı vergi gelirleri ile tüketici fiyat endeksi değişkenleri arasındaki ilişkiyi açıklayan katsayılar tahmin edilmeden önce, bu değişkenler arasında uzun dönemli bir ilişki olup olmadığına ARDL modeline dayalı sınır testi ile bakılmıştır. Sınır testi, Denklem (9) ile ifade edilen modelin en küçük kareler yöntemiyle tahmin edilmesinden sonra, F testine dayalı olarak yapılmaktadır. Modelde yer alan değişkenler arasında eşbütünleşme ilişkisi bulunmadığını ifade eden sıfir hipotezi, standart F-istatistiği kullanılarak test edilmektedir. Hesaplanan test istatistiği kritik değerlerle karşılaştırılarak karar verilmekte, F-istatistiğinin üst kritik değerden büyük olması durumunda sıfır hipotezi reddedilmektedir. Bu doğrultuda; tahmin edilen ARDL (1,0) modelinden hareketle, Denklem (9)'da yer alan $\mathrm{V}_{\mathrm{t}-1}$ ve TUFE $\mathrm{t}_{\mathrm{t}-1}$ değişkenlerine ait parametrelere $\left(\delta_{1}=\delta_{2}=0\right)$ Wald testi uygulanmıştır. Elde edilen $\mathrm{F}$ istatistiği, kritik değerlerle karşılaştırılmış ve sonuç Tablo 5'de gösterilmiştir.

Tablo 5. Sinır Testi Sonuclar

\begin{tabular}{|c|c|c|c|c|}
\hline \multirow{3}{*}{ F-istatistiği } & \multicolumn{4}{|c|}{ Kritik Değerler $(k=1)$} \\
\hline & \multicolumn{2}{|c|}{$\% 1$} & \multicolumn{2}{|c|}{$\% 5$} \\
\hline & I (0) & I (1) & I (0) & I (1) \\
\hline 50,51707 & 8,74 & 9,63 & 6,56 & 7,3 \\
\hline
\end{tabular}

Sınır testi sonucuna göre; hesaplanan F-istatistiğinin \%1 anlamlllk düzeyinde üst kritik değerden büyük olduğu, dolayısıyla $V_{t}$ ve TUFE $E_{t}$ değişkenleri arasında uzun dönemli bir ilişki bulunduğu görülmektedir. Bu durum, söz konusu değişkenler arasındaki ilişkiyi açıklayan uzun dönem katsayılarının ve kısa dönem dinamiklerini gösteren hata düzeltme modelinin tahminini gerekli kılmaktadır. $\mathrm{Bu}$ bağlamda, sınır testinin uygulanması için tahmin edilen model kullanılarak hesaplanan uzun dönem ve kısa döneme ilişkin sonuçlar Tablo 6'da gösterilmiştir.

Tablo 6. Uzun Dönem ve Kısa Dönem Katsayzlar

\begin{tabular}{|c|c|c|c|}
\hline & Katsay1 & Standart Hata & t-istatistiği \\
\hline \multicolumn{4}{|c|}{ Uzun Dönem } \\
\hline TUFE $_{\mathrm{t}}$ & $-1,7124^{a}$ & 0,3030 & $-5,6506$ \\
\hline c & $18,729^{a}$ & 1,4056 & 13,3245 \\
\hline (a) trend & $0,0151^{\mathrm{a}}$ & 0,0021 & 7,10218 \\
\hline \multicolumn{4}{|c|}{ Kısa Dönem } \\
\hline$\Delta$ TUFE $_{\mathrm{t}}$ & $-1,1454^{a}$ & 0,2301 & $-4,9771$ \\
\hline$\Delta(@$ trend $)$ & $0,01014^{a}$ & 0,0017 & 5,85314 \\
\hline$e c t_{t-1}$ & $-0,6689^{a}$ & 0,0672 & $-9,9427$ \\
\hline
\end{tabular}

Yukarıdaki tabloda yer alan uzun dönem katsayılarına bakıldığında, TUFE $t_{t}$ değişkeninin uzun dönem katsayısının $(-1,7124)$ negatif işaretli ve istatistiksel olarak anlamlı olduğu görülmektedir. Dolayısıyla; uzun dönemde enflasyon oranındaki bir değişimin dolaylı vergi gelirlerini ters yönde etkilediği, bir başka deyişle enflasyon oranındaki bir artışın dolaylı vergi gelirlerini azalttığı sonucu ortaya çıkmaktadır. Diğer taraftan; kısa döneme ilişkin hata düzelme modelindeki hata düzeltme teriminin $\left(e c t_{t-1}\right)$ istatistiksel olarak anlamlı ve negatif işaretli olması, hata düzeltme mekanizmasının çalıştığını ve kısa dönemde ortaya çıkan dengeden sapmaların uzun dönemde düzeltilerek dengeye yaklaşıldığını göstermektedir. 


\section{Sonuç}

Dolaylı vergiler ve enflasyon arasındaki ilişki teorik olarak karşılıklı olabilmektedir. Bir başka deyişle; incelenen döneme ve söz konusu dönemde uygulanan politikalara bağlı olarak, dolaylı vergilerin enflasyon oranları üzerinde bir etkisi olabileceği gibi, fiyatlar genel düzeyindeki değişiklikler de dolaylı vergi gelirlerini etkileyebilmektedir. Dolaylı vergilerin enflasyon üzerindeki etkisi iki farklı şekilde ortaya çıkabilmektedir. Bunlardan ilki, antienflasyonist bir etkidir ve Keynesyen maliye politikalarında araç olarak kullanılan dolaylı vergilerdeki bir artışı toplam talebi azaltarak enflasyonu yavaşlatmasını ifade etmektedir. Ancak bu durum, enflasyonun, toplam talepteki otonom bir artıştan kaynaklandığı, yani talep enflasyonunun bulunduğu varsayımı altında geçerli olacaktır. İkinci durum ise, dolaylı vergilerdeki değişikliklerin fiyatları şekillendirmesinden kaynaklanmaktadır. Temelde dolaylı vergiler üretim maliyetini arttıran bir etkendir. Ancak, söz konusu maliyet artışı üretici tarafindan malın fiyatına eklenerek tüketiciye yansıtıldığından, dolaylı vergiler tüketici fiyatlarının bir belirleyicisi olmaktadır. Diğer taraftan; üreticilerin dolaylı vergileri tüketiciye tam olarak yansıtamaması ya da fiyatlardaki bir artışın daha yüksek ücret beklentisine neden olması durumunda maliyetler artacak, bu da maliyet enflasyonuna neden olabilecektir. Dolayısiyla, dolaylı vergilerin fiyatlar genel düzeyi üzerindeki ikinci etkisi enflasyonisttir.

Enflasyonun dolaylı vergiler üzerindeki etkisi ise temelde, fiyatlardaki değişikliklerin vergi matrahını ve dolayısıyla vergi gelirlerini değiştirmesinden kaynaklanmaktadır. Yani iktisadi matrah üzerinden belirlenen dolaylı vergilerdeki enflasyondan kaynaklanan matrah artışı, dolaylı vergi gelirlerini arttırabilecektir. Ancak, enflasyon vergisi olarak da ifade edilen ve enflasyondan kaynaklanan bu artış, reel olmayan bir değişimdir. Bununla birlikte; dolaylı vergilerin fiyat değişimleri karşısındaki esnekliği dolaysız vergilere göre daha düşük olduğundan, dolaylı vergi gelirlerinde enflasyondan kaynaklanan artış da sınırlı olacaktır. Öte yandan bu durum, enflasyonist bir süreçte vergi mükelleflerinin (özellikle de tüketim eğilimi yüksek olan düşük ve orta gelirli kesimin) reel vergi yüklerinin artmasına ve reel gelirlerinin azalmasina da neden olmaktadır. Buna bir de fiyat artşsları eklendiğinde, reel geliri azalan tüketicinin satın alım gücü daha fazla azalacak ve bu durumda toplam talep düşecektir. Dolayısıyla, mal ve hizmetlerden alınan dolaylı vergilerin gelirlerinde, enflasyon nedeniyle bir azalma ortaya çıabilecektir.

Bu çalışmada; Türkiye'de 2004-2019 döneminde enflasyon oranları ile dolaylı vergi gelirleri arasındaki nedensellik ilişkisi, VAR modellerine dayalı olarak gerçekleştirilen Granger ve Toda-Yamamoto (1995) nedensellik testleriyle araştırılmıştır. Enflasyon etkilerinden arındırılmıs dolaylı vergi gelirleri ile ÜFE ve TÜFE arasındaki nedensellik ilişkileri ayrı ayrı incelenmiştir. Elde edilen bulgulara göre, dolaylı vergi gelirleri ile ÜFE arasında herhangi bir nedensellik ilişkisinin olmadığı tespit edilmiştir. Bunun yanında, analiz sonuçlanı, TÜFE'den dolaylı vergilere doğru bir nedensellik ilişkisi olduğunu, yani tüketici fiyat endeksinde meydana gelen değişimlerin dolaylı vergi gelirleri üzerinde anlamlı bir etkisinin olduğunu göstermektedir. Öte yandan, tahmin edilen ARDL modeline dayalı olarak yapılan sinır testi sonucu, TÜFE ile dolaylı vergi gelirleri arasında uzun dönemli bir ilişki olduğunu ve bu ilişkinin negatif olduğunu göstermektedir. Diğer bir ifadeyle; incelenen dönemde enflasyon oranındaki bir artı̧ın dolaylı vergi gelirlerinin reel değerini azalttığı görülmüştür. Sonuç olarak, çalısmanın hipotezi reddedilmekte ve incelenen dönemde dolaylı vergilerin enflasyonla mücadelede etkin bir araç olmadığı söylenebilmektedir. Elde edilen bu sonuçlar; Akıncı ve Özçelik (2018) ile Arısoy ve Ünlükaplan (2011)'n çalışmalarındakilerle ters istikamette olup, Güvenek, Alptekin ve Çetinkaya (2010)'nın sonuçlarıyla büyük oranda örtüşmektedir. Ancak bu çalışmanın kapsamının ve yönteminin, Akıncı ve Özçelik (2018) ve Arısoy ve Ünlükaplan (2011) çalışmalarıyla tam olarak örtüşmediği de göz önünde bulundurulmalıdır.

Analiz sonucunda elde edilen bulgular; Türkiye'de toplam vergi gelirleri içerisinde büyük bir paya sahip olan dolaylı vergilerin, vergi kaynaklı bir enflasyona neden olmadığını göstermektedir. Aynı zamanda, fiyat-ücret sarmalını tetiklemesi veya başka herhangi bir nedenle, üretim maliyetlerini arttırarak maliyet enflasyonuna neden olmadığını da söylemek mümkündür. Dolaylı vergi gelirleri ile üretici fiyatlanı arasında anlamlı bir ilişkinin bulunamaması buna işaret etmektedir. Bu durumun; üreticilerin dolaylı vergilerin tamamını tüketici fiyatlarına yansıtmasından, ayrıca yüksek işsizlik seviyesi ve ilgili yasaların/kurumların iyi işlememesi nedeniyle emek arz edenlerin ücret taleplerinde pazarlık gücünün zayıf olmasından kaynaklandığ tahmin edilmektedir.

Diğer taraftan; analizde enflasyon etkilerinden arındırılarak reel hale getirilmiş dolaylı vergi gelirleri serisinin kullanılmasıyla, enflasyonun matrah artışına neden olarak dolaylı vergi gelirlerini arttırıcı etkisi büyük oranda ortadan kaldırılmıştır. Ayrıca, dolaylı vergilerin fiyat değişimleri karşısındaki esnekliğinin dolaysız vergilere göre düşük olması da bu etkiyi azaltmaktadır. Bu durumda, çalısmanın sonuçları, tüketici 
fiyatlarındaki artısın dolaylı vergi gelirleri üzerindeki azaltıcı etkisinin, toplam talepteki değişimden kaynaklandığına ilişkin kanıtlar sunmaktadır. Bu bağlamda; enflasyonist bir ortamda vergi yükleri artan ve tüketim eğilimi yüksek olan dar gelirli kesimin reel gelirlerindeki azalma, fiyat artışları nedeniyle daha fazla olmuştur. Bu durumda, daha az mal veya hizmet talep ederek daha az harcama yapmışardır. Toplam talebin bu şekilde düşmesi de, harcamalar üzerinden alınan dolaylı vergilerden elde edilen geliri azaltmıştır.

Konuyla ilgili Türkiye üzerine yapılan az sayıdaki çalışmadan bazılarında, dolaylı vergilerin enflasyon üzerinde etkisi olduğu veri iken, bu etkinin incelenmesini amaçlayan modellerin tahmin edildiği görülmektedir. Bu çalışmada ise, herhangi bir ön varsayım yapılmadan, öncelikle bu iki değişken arasındaki ilişkinin yönü belirlenmeye çalışılmıştır. Sonrasında da, tespit edilen nedensellik ilişkisine göre uygun model oluşturularak katsayılar tahmin edilmiş ve yorumlanmıştır.

\section{Etik Beyan}

"Enflasyon ve Dolayla Vergiler Arasındaki Bağlantı: Türkiye Örneğ̨̆" başlıklı çalışmanın yazım sürecinde bilimsel kurallara, etik ve alıntı kurallarına uyulmuş; toplanan veriler üzerinde herhangi bir tahrifat yapılmamış ve bu çalışma herhangi başka bir akademik yayın ortamına değerlendirme için gönderilmemiştir.

\section{Kaynakça}

Akıncı, A. ve Özçelik, Ö. (2018). Türkiye'de dolaylı vergilerin enflasyon üzerindeki etkisi. Maliye ve Finans Yažlar, (110), 9-20.

Arisoy, İ. ve Ünlükaplan, İ. (2011). Katma değer vergisi, enflasyon oranı ve kamu harcamaları arasındaki ilişkilerin dinamik analizi. Sosyoekonomi, 16(16), 93-112.

Asteriou, D. ve Hall, S. (2007), Applied Econometrics a Modern Approach, New York: Palgrave Macmillan.

Brennan, G. ve Auld, D. A. L. (1968). The tax cut as an anti-inflationary measure. Economic Record, 44(4), 520-525.

Brown, R. L., Durbin, J. ve Evans, J. M. (1975). Techniques for testing the constancy of regression relations over time. Journal of the Royal Statistical Society: Series B (Methodological), 37(2), 149-192.

Ciżkowicz M. (2012). Strategia bespośredniego celu inflacyjnego - alternatywne mierniki inflacji. Warszawa: Instytut Ekonomiczny NBP.

Çakmakl, C., Demiralp, S., Yeşiltaş, S. ve Yıldıım, M. A. (2018). Tütün Ürünlerine Uygulanan Dolaylh Vergilerin Enflasyona Etkileri. Koç University-Tüsiad Economic Research Forum Working Paper Series, No: 1811.

Dickey, D. A. ve Fuller, W. A. (1981). Likelihood ratio statistics for autoregressive time series with a unit root. Econometrica, 49(4), 1057-1072.

Eken, M. H. (2000). Enflasyonun bankachlk üzerine etkilerinin risk ve karlhlk açsından değgrlendirilmesi. İstanbul: Boğaziçi Yayınları.

Elkina, M. A. (2019). The impact of indirect tax rates cut on inflation: evidence from Russia. Finansoyyj žburnalFinancial Journal, 5, 37-49.

Engle, R.F. ve Granger, C.W.J. (1987). Cointegration and error correction: Representation, estimation and testing. Econometrica, 55, 251-276.

European Commission, (2016). Taxation Trends in the European Union - Data for The EU Member States, Iceland and Norway. Luxembourg: Publications Office of the European Union.

Görgün, S. (1994). Maliye politikeası-ders notlar (Yayın No. 3). İstanbul: İstanbul Üniversitesi SBF Masaüstü Yayıncillk Birimi.

Güvenek, B., Alptekin, V. ve Çetinkaya, M. (2010). Enflasyon ve dolaylı vergilerden elde edilen gelirler arasındaki ilişkinin var yöntemiyle analizi. Kamu-İs Dergisi, 11(3), 1-28.

Henry, S. G. ve Karakitsos, E. (1986). Inflation, unemployment and indirect taxation. Bulletin of Economic Research, 39(1), 29-47.

Johansen, S. (1988). Statistical analysis of cointegrating vectors. Journal of Economic Dynamics and Control, 12, 231-254.

Karadağ, M. ve Westaway, T. (1999). The impact on consumer and producer prices in Turkey of VAT changes designed to meet EU membership criteria: a computable general equilibrium approach. Economic Research Paper, 99/19, Loughborough University Department of Economics.

Kıran, B. ve Güriş, B. (2011). Türkiye'de ticari ve finansal dışa açıklığın büyümeye etkisi: 1992-2006 dönemi üzerine bir inceleme. Anadolu Universitesi Sosyal Bilimler Dergisi, 11(2), 69-80.

Koutsouvelis, P. ve Papastathopoulos, A. (2013). The effects of indirect taxes on consumer prices: empirical evidence for greece. Advances in Management and Applied Economics, 3(1), 61-76.

Kwiatkowski, D., Phillips, P. C., Schmidt, P. ve Shin, Y. (1992). Testing the null hypothesis of stationarity against the alternative of a unit root. Journal of Econometrics, 54(1-3), 159-178.

Laufenburger, H. (1961). Mali iktisat ve mali kanunlar (Çev: İ. Özüt), Ankara: Ankara Üniversitesi Siyasal Bilgiler Fakültesi Yayınlar1 No: 137/119.

Mansfield, C. (1980). Tax-base Erosion and Inflation: the Case of Ghana. Finance \& Development, 17(3), 31-34.

Możdzierz, A. (2017). The impact of changes in indirect tax rates on inflation in selected EU countries. Annales Universitatis Mariae Curie-Sk.todowska, Sectio H Oeconomia, 51(4), 257-267. 
Narayan, P. ve Narayan, S. (2005). Estimating income and price elasticities of imports for fiji in a cointegration framework. Economic Modelling, 22(3), 423-438.

Nowotny, E. (1980). Inflation and taxation: reviewing the macroeconomic issues. Journal of Economic Literature, 18(3), 1025-1049.

Ongan, M. O. (2002). The Seasonal Adjustment of the Consumer and Wholesale Prices : a Comparison of Census X-11, X-12 Arima and Tramo/Seats. Central Bank of the Republic of Turkey, Research and Monetary Policy Department, Working Papers 0205.

Owsiak, S. (2017). Finanse publiczne w okresie przemian ustrojowych w Polsce. Studia Ekonomiczne/Polska Akademia Nauk. Instytut Nauk Ekonomicznych, 2(93), 177-199.

Quah D. ve Vahey S.P. (1995). Measuring core inflation. The Economic Journal, 105(432), 1130-1144.

Özbilen, Ş. (1997). Vergi - enflasyon ilişkisi. Dokuz Eylül Üniversitesi İktisadi ve İdari Bilimler Fakültesi Dergisi, $12(1), 157-$ 171.

Peacock, A. T. ve Williamson, J. (1967). Consumption taxes and compensatory finance. The Economic Journal, 77(305), $27-47$.

Pesaran, M. H., Shin, Y. ve Smith, R. J. (2001). Bounds testing approaches to the analysis of level relationships. Journal of Applied Econometrics, 16, 289-326.

Phillips, P. C. ve Perron, P. (1988). Testing for a unit root in time series regression. Biometrika, 75(2), 335-346.

Pitchford, J. ve Turnovsky, S. J. (1975). Income distribution and taxes in an inflationary context. Economica, 42(167), 272-282.

Susam, N. (2009). Türkiye'de uygulanan maliye politikalar. İstanbul: Derin Yayınları.

Toda, H. Y. ve Yamamoto, T. (1995). Statistical inference in vector autoregressions with possibly integrated processes. Journal of Econometrics, 66(1-2), 225-250.

Woźniak P. (2002). Inflacja bazowa. Warszawa: Centrum Analiz Społeczno-Ekonomicznych (CASE).

Yavuz, N. Ç. (2006). Türkiye'de turizm gelirlerinin ekonomik büyümeye etkisinin testi: Yapısal kır1lma ve nedensellik analizi. Doğuş Üniversitesi Dergisi, 7(2), 162-171.

\section{EXTENDED ABSTRACT}

The theoretical and empirical studies on the subject reveals that the relationship between inflation and indirect taxes may be bilateral. Generally, the impact of an inflationary process on the tax base explains the part of this two-way relationship from inflation to indirect taxes. It is inevitable that inflation in an economy affects tax revenues or the tax system in general, like many other macroeconomic variables. The effect of inflation on indirect taxes is due to the changes in prices change the tax base and hence tax revenues. In other words, the increase in tax base resulting from inflation in indirect taxes determined over economic base may increase indirect tax revenues. But this increase, which is also referred as inflation tax and results from inflation, is a non-real change. However, since the felicity of indirect taxes against price changes is lower than that of direct taxes, the increase in indirect tax revenues due to inflation is limited. On the other hand, the increase in tax base resulting from the increase in prices increases taxpayers' (especially the low and middle income group with high consumption tendency) tax burden and reduces their real income. When the real income-reducing effect of inflationary process is added, the purchasing power of the consumer decreases more and in this case the total demand decreases. Therefore, a decrease in the revenue of indirect taxes on goods and services may occur due to inflation. In this case, the net change in indirect tax revenues depends on which of the effect of price increases to increase tax base or to decrease total demand is bigger.

On the other hand, the effect of indirect taxes on inflation stems from the fact that changes in tax rates change prices (especially consumer prices). The determinative effect of indirect taxes on prices may cause inflation or a slow down in inflation. In terms of demand, indirect taxes are expected to slow down inflation by reducing total demand. However, this will be valid under the assumption that inflation arises from an autonomous increase in total demand, or in other words there is demand inflation. When it is evaluated in terms of supply, indirect taxes are actually a factor that increases costs and has an inflationary effect. However, indirect taxes become a determinant of consumer prices since the increase in cost is added to the price of the product by the producer and reflected to the consumer. On the other hand, if producers cannot reflect the indirect taxes to the consumer fully, or if the increase in prices leads to a higher wages expectation, then the costs increase and this results in cost inflation.

The aim of this study is to examine the causality relationship between inflation and indirect taxes in Turkey and is to determine whether indirect taxes, as a Keynesian fiscal policy tool in reducing inflation, are effective. In this context the main hypothesis of the study is: "The change in indirect taxes is the reason of the change in the inflation rate." But before such a presupposition, firstly, the direction of the relationship between these two variables is tried to be determined, and then a convenient model is 
generated according to the causality relationship determined and coefficients are estimated and interpreted.

In this context, the 2004-2019 monthly data for Turkey is used and causality relationship between inflation rates and indirect tax revenues is examined with Granger causality test and Toda-Yamamoto (1995) causality approach which are generated on the basis of VAR models. Afterwards, a boundary test is performed with the model created according to the causality relationship determined and coefficients are estimated. Two different indicators, namely producer price index (PPI) and consumer price index (CPI), are used to represent the inflation variable and two separate analysis processes are conducted. According to the findings, it is determined that there is no causality relationship between indirect tax revenues and PPI. In addition, the results of the analysis show that there is a causality relation from CPI to indirect taxes, that is, changes in the consumer price index have a significant effect on indirect tax revenues. On the other hand, the result of the boundary test based on the estimated ARDL model shows that there is a long-term relationship between CPI and indirect tax revenues and this relationship is negative. In other words; it is observed that an increase in the inflation rate in the analyzed period decreased the real value of indirect tax revenues.

As a result, the hypothesis of the study is rejected and it can be said that indirect taxes are not effective tools in combating inflation in the period examined. In addition, findings show that, indirect taxes which have a large share in total tax revenues in Turkey do not result in tax-induced inflation. It is also possible to say that by triggering the price-wage spiral, or for any other reason, by increasing production costs, it does not cause cost inflation. The absence of a significant relationship between indirect tax revenues and producer prices indicates this. It is estimated that this situation is due to the fact that producers reflect all indirect taxes on consumer prices, as well as the weak bargaining power of wage demands of labor suppliers due to the high level of unemployment and related laws/institutions which is not working well.

On the other hand, the indirect tax revenues series, which is made real by clearing off the effects of inflation, are used in the analysis and the effect of inflation that increases the tax base and increases the indirect tax revenues is largely eliminated. In addition, the low flexibility of indirect taxes against price changes compared to direct taxes supports this conclusion. In this case, the results of the study provide evidence that the decreasing effect of the increase in consumer prices on indirect tax revenues is due to the change in total demand. In this context, as their tax burden increases in an inflationary environment, the decrease in the real incomes of the low and middle income group is higher due to the price increases. The decrease in total demand by this way also decreases the revenues from indirect taxes on expenditures. 